\title{
Study of Formulation, Sensory Evaluation and Microbiological Study of Whey Beverage from Camel and Buffalo Milk
}

\author{
Parma Ram Gorachiya ${ }^{1 *}$, Basant Bais ${ }^{1}$, Devendra Kumar ${ }^{2}$, Basant $^{3}$ and Sanjay Singh ${ }^{1}$ \\ ${ }^{1}$ Department of Livestock Products Technology, ${ }^{3}$ Department of Veterinary Microbiology and \\ Biotechnology, College of Veterinary and Animal Science, Bikaner-334001, Rajasthan, India \\ ${ }^{2}$ National Research Centre on Camel, Bikaner-334001, Rajasthan, India
}

*Corresponding author

\begin{abstract}
A B S T R A C T
Whey and juices of pomegranate and watermelon were utilized at various combinations (whey: pomegranate, 89.5:5, 79.5:15 and 69.5:25) (whey: watermelon, 89.5:5, 84.5:10,

Keywords

Formulation, Sensory evaluation, Microbiological study, Buffalo milk

Article Info

Accepted:

18 August 2018

Available Online:

10 September 2018 79.5:15 and 74.5:20) with constant amount of sugar (4.5\%) and black salt (1\%) in all samples. Control treatment $\left(\mathrm{T}_{0}\right)$ was the whey added with sugar and salt as that of treatments for preparation of nutritious beverages and evaluated for sensory attributes and microbial during storage. The storability of the beverage was studied at $4 \pm 1^{\circ} \mathrm{C}$ for 12 days. The study revealed that the beverage prepared with $69.5 \%$ whey and $25 \%$ pomegranate juice and $74.5 \%$ whey and $20 \%$ watermelon juice scored maximum for almost all sensorial quality attributes such as appearance, color, flavor, taste and over all acceptability. From the study it was concluded that fruit juice incorporated whey beverage of good quality could be products as of developed products $(69.5 \%$ whey and $25 \%$ pomegranate juice and $74.5 \%$ whey and $20 \%$ watermelon juice) and the same could be used for its shelf life study during refrigerated storage. The standard plate Counts was high ranging from $4.49 \pm 0.003$ $-5.40 \pm 0.006 \mathrm{CFU} / \mathrm{mL}$. Coliform count was ranging from $2.06 \pm 0.017-2.80 \pm 0.004$. Mould and yeast count varied between $0.0-2.33 \pm 0.009 \mathrm{CFU} / \mathrm{mL}$. This research is aimed at production of whey based beverage.
\end{abstract}

\section{Introduction}

Whey is a valuable by-product obtained during coagulation of milk by using acid and/or rennet or physico-chemical process for the preparation of cheese, paneer, chhana, chakka and casein. The main biological activities of whey proteins are suggested to include cancer prevention, increase of glutathione levels, antimicrobial function and increase of satiety response (Madureira et al., 2007). However, in spite of being a nutritive product, whey is still little used in human diet (Drgalic et al., 2005). Previously, whey was used mainly in animal feed or surplus. With advances in technology and recent discoveries of functional and bioactive roles of whey proteins, whey and whey components are now viewed as precious ingredients. The recognition of whey as a source of unique 
physiological and functional attributes provides opportunity for the food industry to incorporate whey and whey components into a variety of foods. Whey beverages have been recognized as a genuine thirst quencher, light, refreshing, healthful and nutritious (Prendergast, 1985).

By adding some simple ingredients in the whey, like sugar, colour and flavour to it, results in improvement of its nutritive value, taste and acceptability. So utilization of such whey for the conversion into best beverage would be one of the important ways to utilize it. There is a lot of scope to explore the possibility of its utilization in beverage industries (Sakhale et al., 2012).

Fruit extract of Pomegranate (Punica Granatum) can be blended with whey to prepare a health drink. Pomegranate fruit juice is a great source of ellagic acid as antioxidant and omega-5 polyunsaturated fatty acid which is highly beneficial for cell regeneration and proliferation. The juice of this fruit is an exceptional source of vitamin $\mathrm{A}, \mathrm{C}$ and $\mathrm{E}$ and minerals such as calcium, phosphorous, potassium, iron, folic acid, niacin, thiamin, folates and riboflavin. Looking towards all of its health benefits an attempt was made to utilize whey in combination with different proportions of pomegranate juice to develop pomegranate based whey beverage also the inclusion of pomegranate juice makes better the sensory quality and enhances the acceptability of beverage (Negi et al., 2003).

Watermelon (Citrullus lanatus) is one of the most abundant and cheap fruits that is available in India. It is available throughout the year, but production is highest in the summer. This fruit is a rich natural source of lycopene, a compound responsible for its red colour (Perkins-Veazie et al., 2001). Intake of lycopene containing-products has been associated with a reduced incidence of coronary heart disease and some types of cancer (Giovannucci, 2002). Looking towards all of the health benefits of pomegranate and watermelon juice an attempt was made to utilize whey procured from camel and buffalo milk in combination with different proportions of pomegranate and watermelon juice to develop naturally flavoured whey beverages which are nutritious as well as palatable.

\section{Materials and Methods}

\section{Material collection and sample preparation}

Fresh buffalo milk was obtained from buffaloes maintained under the project "Establishment of live demonstration models of diversified livestock production systems for motivating adaption to enhancing agricultural income (RKVY-15)" C.V.A.S., RAJUVAS, Bikaner and was kept at refrigeration temperature till further use. Fresh camel milk was collected from camel dairy maintained at ICAR-NRC on Camel, Bikaner. All samples, collected manually in sterile bottles once per day (usually in the morning).

In a different study on coagulation properties of camel milk for channa production, $70 \%$ of camel milk and $30 \%$ of buffalo milk was standardized for production of channa with good yield and binding properties. The byproducts of that study were used for the preparation of good quality whey beverage. Briefly, admixed milk was heated at $80^{\circ} \mathrm{C}$ and milk was coagulated using $2 \%$ citric acid solution followed by continuous stirring resulted in complete coagulation of milk protein (casein). The liquid (whey) was filtered using muslin cloth and stored for further use. Fresh pomegranate, watermelon, sugar and black salt were procured from the local market to prepare juice for incorporation in whey to form naturally flavoured whey beverages from camel and buffalo milk. Pomegranate juice was extracted from the 
edible part (arils+ seeds). The edible part of pomegranate was grinded in a juicer and the prepared juice was then filtered through a double layered muslin cloth for a clear pomegranate juice and stored. Fresh and best quality watermelon was procured from the local market. For the extraction of juice watermelon was peeled and cut into small pieces. After separating the seeds the fruit pieces were grinded in a mixture and the pulp was then filtered through a double layered muslin cloth and a clear watermelon juice and stored.

\section{Product development}

The different formulations (treatments) of pomegranate based whey beverage were prepared by using constant level of sugar $4.5 \%$ and black salt $1 \%$ in different combinations of whey and pomegranate juice viz. $\mathrm{T}_{0}$ (94.5\%whey: $0 \%$ pomegranate juice), $\mathrm{T}_{1} \mathrm{P}_{1}$ (89.5\%whey: $5 \%$ pomegranate juice), $\mathrm{T}_{1} \mathrm{P}_{2}$ (79.5\%whey: $15 \%$ pomegranate juice) and $\mathrm{T}_{1} \mathrm{P}_{3}$ (69.5\% whey: $25 \%$ pomegranate juice).

The different formulations (treatments) of watermelon based whey beverage were prepared by using constant level of sugar $4.5 \%$ and black salt $1 \%$ in different combinations of whey and watermelon juice viz. $\mathrm{T}_{0}(94.5 \%$ whey: $0 \%$ watermelon juice), $\mathrm{T}_{2} \mathrm{~W}_{1}(89.5 \%$ whey: $5 \%$ watermelon juice), $\mathrm{T}_{2} \mathrm{~W}_{2}(84.5 \%$ whey: $10 \%$ watermelon juice), $\mathrm{T}_{2} \mathrm{~W}_{3}(79.5 \%$ whey: $15 \%$ watermelon juice) and $\mathrm{T}_{2} \mathrm{~W}_{4}$ (74.5\% whey: $20 \%$ watermelon juice). The treatments were heated to dissolve the added ingredients followed by filling into sterilized glass bottles then sealed.

\section{Sensory evaluation}

The beverage samples were evaluated for their sensory characteristics namely color and appearance, taste, flavor and overall acceptability by a trained panels comprising of 10 panelists drawn from faculty members and post graduate students of the Department. The panelists were asked to record their observations on the sensory sheet based on a 8 point hedonic scale ( 8 and 1 points showing like extremely and dislike extremely).

\section{Microbial tests}

Microbiological qualities of the beverage samples are analyzed during storage were examined for the SPC count, coliform count, yeast and mold count. Standard plate count (SPC) was determined with plate count agar medium, and the plates of different dilutions were incubated at $37^{\circ} \mathrm{C}$ for 24 hour. The total number of colonies per $\log (\mathrm{cfu} / \mathrm{ml})$ was determined. Violet Red Bile (VRB) agar medium was used for determination of coliform bacteria and the plates of different dilutions were incubated at $37^{\circ} \mathrm{C}$ for 24 hour by pour plate method, and the number of dark red colonies was calculated. Yeast molds (YM) count take place by Potato dextrose agar (PDA) medium by pour plate method and the plates of different dilutions were incubated at $37^{\circ} \mathrm{C}$ for 24 hour, for yeast and mold count.

\section{Statistical analysis}

All the experiments of study were repeated three times and samples were drawn in duplicate. Data collected during the present investigation were subjected to statistical analysis by adopting appropriate methods of analysis of variance as described by Snedecor and Chochran (1994).

Wherever, the variance ratio were found significant at 5 per cent and highly significant at 1 per cent levels of probability, the significance of mean differences were tested by Duncan's New Multiple Range Test (Duncan's Range Test) as modified by Kramer (1957).

\section{Results and Discussion}




\section{Sensory evaluation}

The treatments (beverages) in figure 1 indicate that the panelists, on average, prefer the treatments $\quad \mathrm{T}_{1} \mathrm{P}_{3} \quad$ (69.5\% whey: $25 \%$ pomegranate juice) in pomegranate based whey beverage and $\mathrm{T}_{2} \mathrm{~W}_{4}$ (74.5\% whey: $20 \%$ watermelon juice) in watermelon based whey beverage for, appearance/ colour, flavor, taste and overall acceptability.

To summarize, it can be concluded that $\mathrm{T}_{1} \mathrm{P}_{3}$ made with $69.5 \%$ whey, $25 \%$ pomegranate juice, $4.5 \%$ sugar and $1 \%$ black salt is the most appreciated in pomegranate based whey beverage and $\mathrm{T}_{2} \mathrm{~W}_{4}$ made with $74.5 \%$ whey, $20 \%$ pomegranate juice, $4.5 \%$ sugar and $1 \%$ black salt is the most appreciated in watermelon based whey beverage. Hence these formulas were used to evaluate microbial quality of beverage at refrigeration temperature. For further studies $\mathrm{T}_{1} \mathrm{P}_{3}$ used as $\mathrm{T}_{1}, \mathrm{~T}_{2} \mathrm{~W}_{4}$ used as $\mathrm{T}_{2}$ and control as $\mathrm{T}_{0}$. The result of sensory evaluation of naturally flavoured whey beverages has been shown in figure 1.

\section{Microbial analysis}

The beverage samples were analysis periodically for total plate count and mould and yeast count. The data obtained with respect to microbial load are summarized in Table 1. Total standard plate count of bacteria increases and after the completion of (12 days) storage it reaches from $4.49 \pm 0.003 \mathrm{log}$ $(\mathrm{cfu} / \mathrm{ml}), 4.60 \pm 0.008 \log (\mathrm{cfu} / \mathrm{ml})$ and $4.53 \pm$ $0.011 \log (\mathrm{cfu} / \mathrm{ml})$ to $5.42 \pm 0.074,5.40 \pm$ 0.006 and $5.38 \pm 0.002$ in sample $\mathrm{T}_{0}, \mathrm{~T}_{1}$ and $\mathrm{T}_{2}$ respectively. Ismail et al., (2011) studied the microbial and chemical evaluation of whey based mango beverage and reported that standard plate count significantly increased with increase of storage of whey based mango beverage. Similar results was obtained by Yonis et al., (2014) who studied the utilization of sweet whey in production of whey guava beverages and observed significant increase in the standard plate count with increase of storage period.

Fig.1 The result of sensory evaluation of naturally flavoured whey beverages

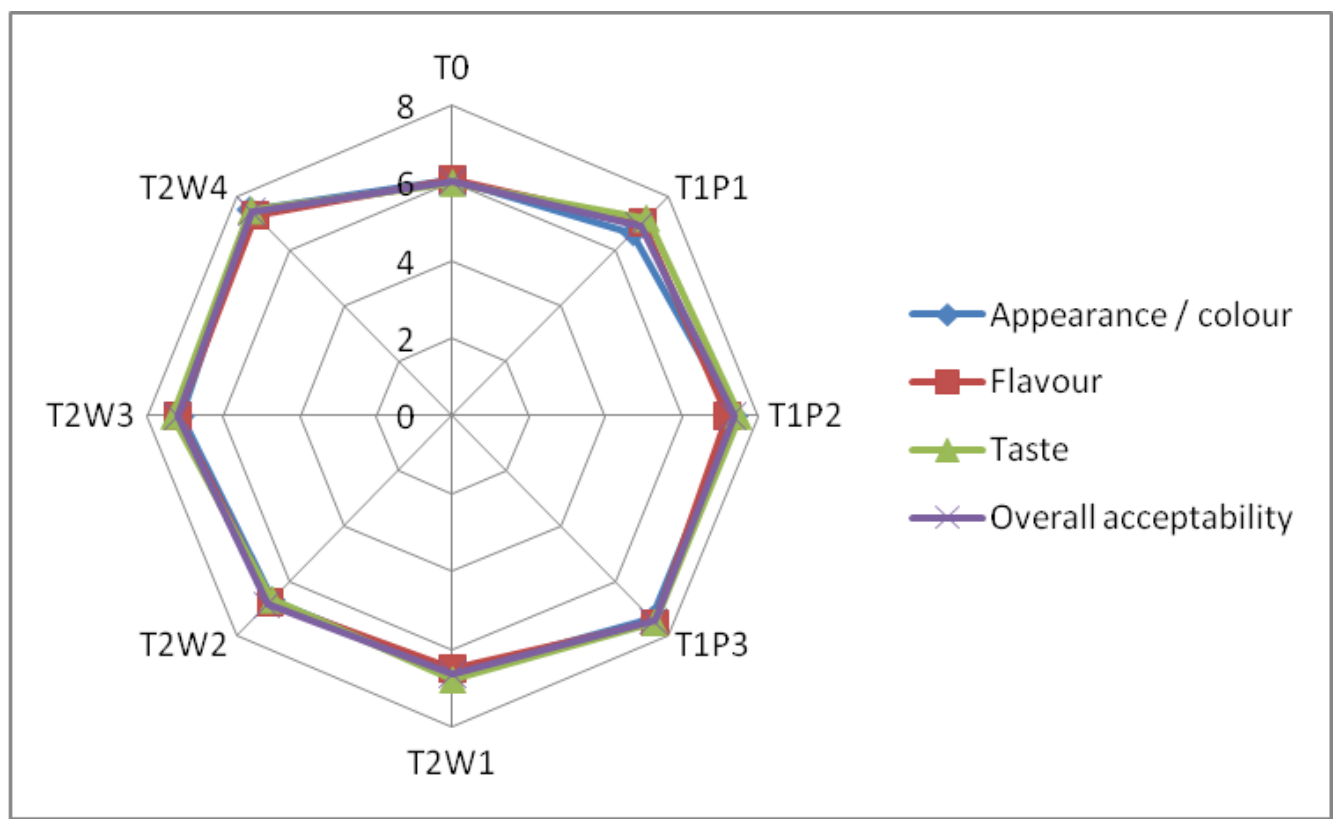

Table.1 Microbial analysis of whey beverages 


\begin{tabular}{|c|c|c|c|c|}
\hline \multirow[t]{2}{*}{ Parameter } & \multirow{2}{*}{$\begin{array}{l}\text { Storage } \\
\text { period }\end{array}$} & \multicolumn{3}{|c|}{ Samples } \\
\hline & & T0 & $\mathrm{T} 1$ & $\mathrm{~T} 2$ \\
\hline \multirow{5}{*}{$\begin{array}{l}\text { Bacterial count } * * * \\
(\mathrm{CFU} / \mathrm{ml})\end{array}$} & 0 & $4.49^{a} \pm 0.003$ & $4.60^{\mathrm{a}} \pm 0.008$ & $4.53^{\mathrm{a}} \pm 0.011$ \\
\hline & 3 & $4.76^{b} \pm 0.003$ & $4.84^{b} \pm 0.011$ & $4.78^{b} \pm 0.003$ \\
\hline & 6 & $4.94^{c} \pm 0.002$ & $5.09^{c} \pm 0.003$ & $5.04^{c} \pm 0.006$ \\
\hline & 9 & $5.19^{d} \pm 0.001$ & $5.27^{d} \pm 0.006$ & $5.23^{d} \pm 0.006$ \\
\hline & 12 & $5.42^{\mathrm{e}} \pm 0.074$ & $5.40^{\mathrm{e}} \pm 0.006$ & $5.38^{\mathrm{e}} \pm 0.002$ \\
\hline \multirow{5}{*}{$\begin{array}{l}\text { Coli form count } \\
(\mathrm{CFU} / \mathrm{ml})\end{array}$} & 0 & Nil & Nil & Nil \\
\hline & 3 & Nil & Nil & Nil \\
\hline & 6 & $2.06^{\mathrm{a}} \pm 0.017$ & $2.23^{\mathrm{a}} \pm 0.010$ & $2.15^{\mathrm{a}} \pm 0.018$ \\
\hline & 9 & $2.29^{b} \pm 0.010$ & $2.53^{b} \pm 0.006$ & $2.50^{b} \pm 0.008$ \\
\hline & 12 & $2.55^{c} \pm 0.007$ & $2.80^{c} \pm 0.004$ & $2.72^{c} \pm 0.007$ \\
\hline \multirow{2}{*}{$\begin{array}{l}\text { Yeast and mould } \\
\text { count }(\mathrm{CFU} / \mathrm{ml})\end{array}$} & 0 to 9 days & Nil & Nil & Nil \\
\hline & 12 & $2.19 \pm 0.013$ & $2.33 \pm 0.009$ & $2.25 \pm 0.009$ \\
\hline
\end{tabular}

$* *=$ Significant at $1 \%(\mathrm{P}<0.01)$

The coliform count was not observed at day 0 and 3 in sample $T_{0}, T_{1}$ and $T_{2}$, respectively. Coliform count increases from day 6 to day 12 from $2.06 \pm 0.017 \log (\mathrm{cfu} / \mathrm{ml}), 2.23 \pm$ $0.010 \log (\mathrm{cfu} / \mathrm{ml})$, and $2.15 \pm 0.018 \log$ $(\mathrm{cfu} / \mathrm{ml})$ to $2.55 \pm 0.007 \log (\mathrm{cfu} / \mathrm{ml}), 2.80 \pm$ $0.004 \log (\mathrm{cfu} / \mathrm{ml})$, and $2.72 \pm 0.007 \mathrm{log}$ (cfu/ml) in sample $\mathrm{T}_{0}, \mathrm{~T}_{1}$ and $\mathrm{T}_{2}$, respectively. Ismail et al., (2011) studied the microbial and chemical evaluation of whey based mango beverage and reported that the coliform count was significantly increased with increases of storage period of whey beverage. Similar results were also obtained by Yonis et al., (2014) who studied the utilization of sweet whey in production of whey guava beverages and observed significant increase in the coliform count with increase of storage of whey beverage.

Mould and yeast count was not detected in all three samples (T1, T2, T3) upto 9 day of storage whereas it observed on $12^{\text {th }}$ day were $2.19 \pm 0.013 \log (\mathrm{cfu} / \mathrm{ml}), 2.33 \pm 0.009 \mathrm{log}$ $(\mathrm{cfu} / \mathrm{ml})$ and $2.25 \pm 0.009 \log (\mathrm{cfu} / \mathrm{ml})$ in sample $T_{0}, T_{1}$ and $T_{2}$, respectively. In spite of the potential benefits offered by fruit juices, concerns over their safety and quality have been raised; as freshly prepared juices have no process or steps to minimize the microorganisms if they are contaminated (Mahale et al., 2008).

It can be concluded that whey can be found successful for the development of pomegranate and watermelon based whey beverages with optimum sensory characteristics. The nutritious beverages with better storage life could be developed by addition of whey up to certain extent. In this study, whey is successfully utilized to develop a watermelon-based fruit beverage with optimum sensory and nutritional properties as well as good storage stability. The beverage possesses high colour, flavour and stability properties. A nutritious beverage with better storage life is developed with the addition of whey, watermelon juice, sugar and black salt in appropriate proportion. In view of the functional properties arising from bioactive 
constituents present in fruit and whey, it is proposed that pomegranate based whey beverages with excellent nutritional, sensory and storage properties could be an interesting product in the constantly growing market for functional foods.

\section{References}

Drgalic, I., Tratnik, L., and Bozanic, R. (2005). Growth and survival of probiotic bacteria in reconstituted whey. Dairy Sci. and Technoogy., 85, 171179.

Giovannucci, E. (2002). A review of epidemiologic studies of tomatoes, lycopene, and prostate cancer. Experi. Bio. and Med. 227(10), 852-859.

Ismail, A. E., Abdelgader, M. O., and Ali, A. A. (2011). Microbial and chemical evaluation of whey-based mango beverage. Advance J. Food Sci. and Technology., 3(4), 250-253.

Kramer, C.Y. (1957). Extension of multiple range tests to group correlation adjusted means. Biometrics 13: 13.

Madureira, A. R., Pereira, C. I., Gomes, A. M. P., Pintado, M. E. and Xavier Malcata, F. (2007). Bovine whey proteins-
Overview on their main biological properties. Food Res. Int. 40:1197-1211

Negi, P. S., Jayaprakasha, G. K., and Jena, B. S. (2003). Antioxidant and antimutagenic activities of pomegranate peel extracts. Food Chem., 80(3), 393397.

Perkins- Veazie, P., Collins, J. K., Pair, S. D., and Roberts, W. (2001). Lycopene content differs among red-fleshed watermelon cultivars. J. Sci. Food and Agri., 81(10), 983-987.

Prendergast. (1985). Whey drink, Technology Processing and Marketing. J. Sci. Dairy Technology, 38: 103.

Sakhale, B. K., Pawar, V. N., and Ranveer, R. C. (2012). Studies on the development and storage of whey based RTS beverage from mango cv. Kesar. $J$. Food Processing \&Technol., 3(3).

Snedecor, G.W. and Cochran, W.G. (1994). Statistical methods, $8^{\text {th }}$ Edn.The Iowa State University Press, Ames, Iowa, U.S.A.

Yonis, A.A.M.; Rasha M. Nagib and Lobna, A. AboNishouk. (2014) Utilization of sweet whey in production of whey guava beverages. J. Food and Dairy Sci., Vol. 5 (10): 731 - 739.

\section{How to cite this article:}

Parma Ram Gorachiya, Basant Bais, Devendra Kumar, Basant and Sanjay Singh. 2018. Study of Formulation, Sensory Evaluation and Microbiological Study of Whey Beverage from Camel and Buffalo Milk. Int.J.Curr.Microbiol.App.Sci. 7(09): 2630-2635. doi: https://doi.org/10.20546/ijcmas.2018.709.328 